\title{
Acculturation and decoupling processes on attitudes towards gay marriage: A survey study in Denmark and the Netherlands among Russian Christian and Turkish Muslim migrants
}

\author{
Dr Jeanette A.J. Renema
}

National University of Singapore, Social Service Research Centre (SSR)

jeanette.renema@gmail.com

Dr Marijn van Klingeren ${ }^{b}$

Radboud University Nijmegen, Sociology, Radboud Social Cultural Research (RSCR).

m.vanklingeren@maw.ru.nl

September 21, 2021

\begin{abstract}
Within Europe, migrants are often the subject of societal debate, stressing the incompatibility of outside cultures with so-called Western values. Through Social Identity Theory we investigate how first-generation migrants adapt their attitudes towards gay marriage. We compare Turkish Muslim to Russian Orthodox Christians. Adaptation processes (acculturation and decoupling) are investigated in both migrant groups in the Dutch and Danish context, in light of degree of religiousness and home-country connectivity. Our results indicate that adaptation takes place through a decoupling mechanism both for Turkish Muslim and Russian Orthodox with regards to the degree of religiousness. Meaning that those who have been in the receiving country longer are more likely to adapt their attitudes, regardless of their religiousness. This process appears much slower among Turkish Muslims than among Russian Orthodox Christians.
\end{abstract}




\section{Introduction}

West-European democracies are facing turbulent times. With increased immigration, questions have risen with concern to how these developments affect the European (socio-) democratic values and West-European political systems (Breidahl \& Larsen, 2016; Dinesen, 2013; Röder \& Mühlau, 2014). Politicians often put specific emphasis on the threat of a rising Islam to European culture (Inglehart, 1997), because Islamic values are argued to be incompatible with progressive West-European cultural values (Shield, 2017; Spierings et al. 2015). Evidence links (Muslim) piety to low support for gender equality or gay rights (e.g. David \& Greenstein, 2009; Frejka \& Westoff, 2008; Inglehart, 1997; Norris \& Inglehart, 2012; Röder \& Lubbers, 2015). Yet, research also shows that Islam is not the only religion that openly expresses negative views on homosexuality (Anderson \& Koc, 2015; Roggemans et al., 2015; Van den Akker et al., 2013); other denominations have similar strict norms with regard to gender roles or lesbian, gay, bisexual, and transgender [LGBT]-rights, often imposed through the uphold of family norms (Röder \& Lubbers, 2015). And so, we wonder whether it is fair to emphasize differences in Muslim migrants solely. Therefore, we study Turkish Muslim migrants in relation to a second migrant group with strong religious values: Russian Christian Orthodox migrants (Adamczyk \& Pitt 2009; Van Den Akker, Van Der Ploeg \& Scheepers, 2013).

Previous research also tells us that migrants tend to adjust their attitudes over time, as they move more closely towards the general public opinion of their receiving countries (Cochrane, 2013; Van Klingeren \& Spierings, 2020; Berry, 1980; Röder, 2015), and that this does not always coincide with a reduction in religiosity. Röder (2015) and others have studied whether religious disengagement has caused Muslim and Eastern-European migrants to adapt their overall attitudes (i.e., acculturation; (Röder \& Lubbers, 2015, 2016; Röder \& Mühlau, 2014)), or whether this happens because attitudes disconnect from religious identity (i.e., 
decoupling), or perhaps even both (Van Klingeren \& Spierings, 2020; Röder, 2015). The underlying argument is that there are generally strong linkages between people's level of religiosity and norm-based attitudes, as both are considered crucial parts of one's identity (Anderson \& Koc, 2015; Inglehart, 1997; Verkuyten \& Martinovic, 2012). The previous studies in the field have shown that the connection between religiosity and Western moral values tends to become weaker with every generation, we wonder however about the role of religiosity in the process of attitude adaptation among first generation migrants. We innovate on these studies by also questioning the role of connectivity to home-country members (the ingroup), by studying Turkish and Russian migrants' connection to other Turkish and Russian migrants, in the receiving country, respectively.

As such, group loyalty may well play a key role in these adaptation processes (Phinney, 1990; Sears \& Levy, 2003), or a lack thereof. Socialisation in the origin country can impose certain universal value-structures onto people that change once they are confronted with new value structures in the receiving country. However, the origin country value-structures are more likely to uphold if migrants keep strong ties with other Turkish/Russian migrants (Tajfel \& Turner, 1979). Both migrants' religious- and social identities may have a similar impact on attitudes and whether attitudinal changes happen. We question whether both migrant groups undergo similar attitudinal transformations a longer period after migration and how these two types of identities play a role in attitudes towards gay marriage.

We thus add to the literature in two ways, 1) by examining whether attitude adaptation processes among first generation migrants are dependent upon migrant group denomination and seeing for whom the degree of religiousness and identification is more flexible. And 2) by looking at whether ingroup connectivity plays a similar role in the adaptation process. Our research question reads: whether and to what extent does migration affect the relationship between religious-/ ingroup connectivity and attitudes towards gay marriage among Muslim 
Turkish and Russian Orthodox Christians? We study this question in two highly similar receiving countries: Denmark and the Netherlands.

Eventually this provides us with crucial information on the flexibility of religious and social norms in a more secular setting. Comparing migrant groups with different, yet mostly denomination-related identities will tell us whether the focus on Muslims as a distinctively different minority is apt (Kashyap \& Lewis, 2013). It will also inform us about the generalisability of these processes to other origin countries. Furthermore, by homing in on the developments among first-generation migrants, we get a better idea of whether and how socialising processes take place after the formative years.

We apply data that are part of the Migrants' Welfare State Attitudes (MIFARE) survey dataset, which was administered between the end of 2015 and beginning of 2016. The project was set out to strictly assess attitudes of first-generation migrants from various groups towards various societal themes (Bekhuis \& Hedegaard, 2018), among which attitudes towards gay marriage. ${ }^{1}$

\section{Context: Russian and Turkish immigrants in Denmark and the Netherlands}

To sketch the context of the study, we briefly describe the situation of the two migrant groups and their migration history in the two receiving countries Denmark and the Netherlands.

\section{Turkish Immigrants}

Among Turks, Islam is by far the largest religion ( 82 percent). The majority of Turks is Sunni (about 65 percent), followed by a minority of Alevi and Sufi (IPSOS, 2016). Europe has a long history with regard to Turkish migration, dating back to the Ottoman Empire. Yet, more 
recent first-generation Turkish migrants consist mostly of post-war 'guest workers', their families, and descendants who arrived to the continent from the 1940s to 1970s (Castles, 2006).

The Netherlands stimulated foreigners to perform temporal work from the late 1960s to the mid-70s (Renema \& Lubbers, 2019). Denmark recruited people mostly from Turkey and Yugoslavia during the same period as the Netherlands, yet in much smaller numbers. Turkish immigration in Denmark only started to increase in the 1980s and 90s, after the Geneva conventions, which allowed for political asylum within Europe (Liebig, 2007). The first generation also grew due to family reunification leading to approximately 63,000 (1.1 percent) Turkish migrants in 2017 (Statistics Denmark, 2017) and 400,000 (2.3 percent) Turkish migrants in the Netherlands (Statistics Netherlands, 2018). Since the 2000s, other motives for migration became more prominent and Western-Europe got acquainted with the arrival of highly skilled Turkish migrants. Although this group of migrants is still somewhat smaller in size (Cesur et al., 2018), it can be categorized as more modern and progressive than the migrants that arrived in the host societies in the $60 \mathrm{~s}$ and $70 \mathrm{~s}$.

\section{Russian Immigrants}

In contemporary Russia, almost 70 percent of Russians consider themselves Christian. The Russian Orthodox Church (reformed church, post-Nikonian) is the largest denomination. 6 Percent identifies as Muslim and there is only a small proportion of Russians (less than 1 percent) who identify as either not religious or belonging to another denomination (Sinelina, 2015). After the fall of the former Soviet Union (1989), a surge in disappointment in the (Sovietera) atheist-driven political ideologies were predominant. This resulted in an increase of religious consciousness with the Russian Orthodox Church (ROC) (Sinelina, 2015). Religion was no longer repressed by the state and the state-rebuilding narrative was partly marked by a resurgence of Russian Orthodoxy in public life spheres (Evans and Northmore-Ball, 2012). 
Migration from Russia to other countries took place mostly after the Soviet period, and more women than men migrated towards Western-European countries (Statistics Netherlands, 2012). These numbers are much lower than of Turkish migrants.

Unfortunately, Russian migrants have not often been the subject of academic literature within the attitudinal field, and so we know very little about them. What we do know however, from predominantly qualitative empirical research, is that the majority of Russian migrants arrived in the Netherlands and Denmark after 2000 (Bekhuis et al., 2018), and that in the case of the receiving countries under investigation, Russian migrants are mainly perceived as a group of foreign-born Eastern Europeans that are often associated with crime activities. Or in the case of Russian females, transnational marriages or the sex-industry (Willet, 2007).

\section{Receiving Countries: Denmark and the Netherlands}

By selecting two comparable receiving countries, various important contextual characteristics are held constant. First, Denmark and the Netherlands have a long modern history as receiving countries, and both have seen a steady increase of new-comers in the last decades (Castles, 2010, 2017). Second, their migrant population demographics show similar trends in ethnicity, cultural background and religiosity (Jensen et al., 2010; Berkhout and Sudulich, 2011). Another important factor of compatibility is that both countries have seen a substantial decline in church membership and attendance (12 percent in Denmark and 18 percent in the Netherlands (Pew Research Center, 2018). Furthermore, in both countries the acceptance rate of same-sex romantic involvements is comparatively high: 63 percent in Denmark and 74 percent in the Netherlands. The same thing cannot be said for more religious countries (International Social Survey Programme, 1991, 1998, 2008).

\section{Theoretical Framework}




\section{Religiosity and Attitudes Towards Gay Marriage}

The notion that religiosity goes hand-in-hand with conservative attitudes is by no means new (Thornton, Alwin \& Camburn, 1983). Hence, a great deal of previous research has focused on the association between the level of religiosity and moral conservatism in relation to the immigrant-native disparities in religiousness (e.g. Berry, 1980; Röder, 2015; Van Klingeren \& Spierings, 2020). Denomination has been found to matter greatly in the extent to which religion plays a role in attitudes towards alternative sexual orientation (Anderson \& Koc, 2015; Roggemans, Spruyt, Droogenbroeck \& Keppens, 2015; Van den Akker et al., 2013). And to gender equality for that matter (Alexander \& Welzel, 2011; Glas, Spierings \& Scheepers, 2018). Van den Akker et al. (2013) found that, while using the European Social Survey [ESS], "Muslims disapprove of homosexuality the most [...] Jews and Catholics disapprove of homosexuality less than non-religious persons, whereas Protestants, Eastern Orthodox, other non-Christians and other Christians disapprove of homosexuality more than non-religious" (p.75). Similarly, Roggemans et al. (2015) showed that although the level of religiosity among both Christian- and Muslim youth led to more negative attitudes towards homosexuality, young Muslims with strong to semi-strong ties to their religion were the most averse.

\section{Acculturation and the Expected Role of Religiosity}

Our respondents are first generation adult migrants (both Turkish and Russian) who have spent most of their childhood and teenage years in the origin country (up till at least 16 years). As a result, the internalization of norms is likely to be affected to a great degree by the origin country's moral conviction (Inglehart, 1997). For example, Van den Akker et al. (2013) found that disapproval of homosexuality is the highest in countries that have restrictive laws, and that the latter largely coincides with high levels of religiosity within a nation state. It therefore makes sense that at the time of arrival, immigrants from these very religious/ restrictive countries, who themselves hold strong religious affiliations, would express 
conservative attitudes towards homosexuality. Especially towards gay marriage, since marriage represents the institutionalized acknowledgment of homosexuality (Kite \& Whitley, 1996).

The classical understanding of the assimilation theory predicts that these attitudes should change over time, as people get accustomed to the norms of the more secular host society (Alba \& Nee, 2003). Or as Wimmer (2008) argued, immigrants may wish to shift their status from the minority to the majority by repositioning themselves through assimilation processes; Instead of actively contesting their group's institutional blockages for full assimilation to the host society. In terms of acculturation in Western-Europe, this means that over time migrants are likely to adopt a more secular lifestyle that coincides with a loosening of their religiouslyrelated attitudes. This eventually would lead to a situation in which there are no more substantial differences between natives and migrants with respect to their level of religiousness (Van Tubergen \& Sindradóttir, 2011), or other related attitudes (Röder, 2014). We are therefore interested in understanding whether acculturation effects take place across time among first generation migrants of both migrant groups. Thus, we formulate the following hypothesis: Hla: The length of migration is positively associated with acceptance of gay marriage through lower religiosity.

However, the level of adaptation between the two migrant groups is likely to differ. One reason to believe that acculturation processes are less common among Turkish Muslims than Russian Orthodox Christians, is the fact that religion is in many ways more intertwined with identity for the former group. Even though various European survey studies have showed that mosque-attendance is relatively moderate among Muslims in Western Europe, religious commitment, and communal gatherings with religious traits such as almsgiving and fasting during the Ramadan, play a large role nonetheless (Van Klingeren \& Spierings, 2020). Religious gatherings have a social function for Muslim migrants, especially for women (ibid.). Although the social relationships amongst Russian migrants are considered to be of great 
importance, religion or religious activities are rarely at the core of these gatherings (Kopnina, 2005; Staring, 1999). Making religion less part and parcel of their social identity. Therefore, we expect: H1b: The length of migration is more strongly positively associated with acceptance of gay marriage through lower religiosity for Russian Orthodox Christians than for Turkish Muslims.

\section{Decoupling: Migration Having a Debilitating Effect on the Religiosity-Attitude Connection}

There are several reasons to assume, however, that acculturation does not happen through religious adaptation or through religious adaptation only. Not lastly because of the above-mentioned reason that religious gatherings have a social function. At the mosque or during important Islamic holidays, Muslims meet their families and friends. While Christians meet at church during Christmas and Easter, making it very difficult to completely abandon this element of their identity. However, where religiosity is often directly linked to a migrant's social identity, this is not necessarily the case for related attitudes. Thus, letting go of these attitudes does not mean a total abandonment of one's religious social identity (Barlas, 2002; Glas et al., 2018). Consequently, migration and exposure to dominant attitudes of the host society through signals and discussions in the democratic process (Tétreault et al., 2009) or progressive family laws (Htun and Weldon, 2015) may trigger a change in terms of attitudes, but not in terms of religious identification (Glas et al., 2018; Röder, 2014). Meaning people could hold onto their religious identity while adapting their attitudes to the majority view.

This can be explained by Tajfel and Turners (1979) Social Identity Theory (SIT), which argues that every person is looking to achieve a positive social identity. This can be acquired through social comparison of one's own group to that of others. If by comparison your group is somehow inferior to another group, you are likely to seek change for this situation (Taylor \& 
Moghaddam, 1987). This mechanism thus assumes partial adaptation through decoupling or relaxing of peoples' religiously related attitudes.

To establish change, group members may apply certain identity-compensation strategies, of which social mobility is one (i.e., leaving behind certain elements of the origin group by adapting to the majority). Assimilation could lead to complete absorption into the majority group; however, this may come at the high price of completely abandoning one's initial group. Religion in the cases under study may just have an important identifying function in the host society (Güngor et al., 2012; Sinelina, 2015). Therefore, it is unlikely that migrants will completely abandon it. But norms are more flexible and by becoming more open to equal rights for women or queers, or more accepting of their existence, one can adapt somewhat and thus rise in status socially, while at the same time remaining part of one's religious group. A similar strategy was suggested by Wimmer (2008) in his work on the repositioning strategy. Meaning that a person may 'climb' to other societal positions through adaptation processes without contesting the hierarchical status quo. We therefore hypothesize: H2a: Migration length will lead to decoupling between migrants' religious identification and acceptance of gay marriage.

This process may be happening among Turkish and Russian immigrant groups alike, as it is an easy way to maintain the religious part of one's identity while at the same time adapting to the host-country's liberal norms. Yet, we do expect one strategy to be more likely than the other. As Evans and Northmore-Ball (2012) have shown with their longitudinal analyses, the often observed and reported revival of religious connectivity and church affiliations are clearly visible in modern Russia. The intensity of this revival seems to generally follow the influence of the Christian-Democrat parties in Europe (ibid.). One voice within a coalition of voices in terms of the preferred degree of moral conservatism in society. Thereby, Russian Orthodox identities are generally quite compatible with that of the receiving countries (that are historically 
Christian-embedded). As such, Russian Christians may feel less of a need to adapt their level of religiosity, but since their social identities may still be inferior, we expect that adaptation in attitudes (i.e., decoupling) happens more frequently within this group, while adaptation through reduced religiosity is scarcer. Hence, we formulate our next hypothesis: H2b: for Russian Orthodox Christians the process of decoupling is more likely than that of full acculturation.

Meanwhile, for Turkish migrants it may be harder to climb up the ladder of social hierarchy. The distance between Muslim religion and European norms may be perceived as too large to overcome simply by adapting one's attitudes. Hence, although decoupling is still the most likely process to observe even within this group, H2c: compared to Russian Orthodox Christians we expect to observe full acculturation more often among Turkish Muslim migrants.

\section{Social (Migrant-Group) Connectivity}

Now that we have established the expected connections between migration, religiosity and attitudes, we continue to the role of social connection. Research has argued for the role of the social context in the development of migrants' individual values and attitudes (e.g. Alesina, Baqir \& Easterly, 1999; Klor \& Shayo, 2010). Prior research has found a link between connectivity to the own migrant group in the receiving country and acculturation processes (Maliepaard, Lubbers, \& Gijsberts, 2010; Röder \& Lubbers, 2016). We argue that maintaining strong ties with other ingroup members affects the degree to which people are willing to apply identity-management strategies. Strong sentiments towards the migrant-group have been found to hamper acculturation processes before (Alba \& Nee, 2003). Migrants are more likely to stick to the norms of origin-country identity, if they show a high level of loyalty or connectivity to this group (Klor \& Shayo, 2010). Especially among first-generation migrants the direct connection with other people from the origin country is expected to be relatively high. The first generation is also more likely to be in touch with family members or to make friends with, or 
connect to, people who share the same background in the country of arrival (Nannestad, Svendsen \& Svendsen, 2008).

Yet, the connection to the own migrant group could also be subject to deterioration with more time spend in the host society, leading to attitude adaptation in the long run. In other words, it might not (only) be religious acculturation, but also connective acculturation that causes migrants to adapt to host-society norms. All-in-all, a similar line of reasoning of a religious decoupling mechanism can be considered with regard to home-country connectivity. It is much easier to adapt one's attitudes to those of the receiving society, yet the connectivity one feels to the origin country, a part of one's social identity, is less easily abandoned. We formulate our final two expectations: H3a: Migration length leads to greater acceptance of gay marriage through lower home country connectivity; and H3b: migration length leads to decoupling between migrants' home-country connectivity and acceptance of gay marriage.

\section{Research design and data}

\section{Data}

For our analyses we used the Migrants' Welfare State Attitudes' survey (MIFARE), containing survey data of 10 first-generation migrant groups in Denmark, the Netherlands, and Germany with natives as the respective control groups (Bekhuis et al., 2018). The fieldwork period took place between December 1, 2015 and January 25, 2016. For reasons of validity and reliability, the MIFARE questionnaire is comprised of items from other renowned large-scale cross-national survey programs, such as the International Social Survey Programme [ISSP]. To answer our research question, we selected Turkish Muslims, Russian Christians and nonreligious Russian- and Turkish migrants in Denmark and the Netherlands. In order to have compatible groups for both counties, only migrants from the late 1980s onwards are included 
in the analyses, given that Denmark only really started receiving immigrants from that time onwards.

\section{Sampling}

For the Netherlands, nation-wide net samples of 1100 Russian and 1100 Turkish firstgeneration immigrants between the ages of 18 and 75 years were drawn for each origin country by Statistics Netherlands (CBS). Participants had to be older than 15 upon emigration for them to be proper first-generation migrants who were socialized in the country of origin. Only Russian immigrants born on the soil of current Russia were included, controlling for the differences in boundaries between the former Soviet Union and the Russian Federation. For the Danish sampling technique, the procedures and inclusion criteria were similar, except for net samples of 1000, and only immigrants who have lived in Denmark for at least 12 months were selected (Bekhuis et al., 2018). ${ }^{2}$

\section{Response Rates}

To reduce non-response, financial incentives were given, and participants had the opportunity to complete the postal survey either offline or online and in the receiving country's language or their respective native tongue. The net response rates were the highest among Russian immigrants: 47 percent in the Netherlands (475) and 40.8 percent in Denmark (408). The Turkish response rates were lower; 22 percent in both countries (212 for the Netherlands and 216 for Denmark).

\section{Representation}

In terms of the background characteristics gender, age, household composition, labormarket position) the Danish subsamples were found to be representative (Bekhuis \& 
Hedegaard, 2018). Though such extensive comparisons between response and non-response rates with population data were not possible for the Netherlands, a comparison of the Turkish sample with both registration data on benefit recipiency (by origin country) and earlier Dutch migrant survey datasets (Sociale Positie en Voorzieningengebruik Allochtonen [SPVA] 2002, Nederlandse LevelsLoop Studie [NELLS] 2010, and Survey Integratie Minderheden [SIM] 2011) showed that the MIFARE data show a small overrepresentation of Turkish and Russian migrants who take-up an unemployment benefit (Statistics Netherlands, 2016) and a benign underrepresentation of lower educated Turkish migrants. For a unique migrant dataset such as this, this level of compatibility with the population is nonetheless very promising. Even more so since the newest migration out-flow from Turkey are generally higher educated than the previous outflows (Cesur et al., 2018). Henceforth, since the MIFARE data does seem to reflect the latest migrant population demographics, as well as a lack of accurate population information, we decided not to weigh the data.

\section{Dependent Variable}

Immigrants' acceptance of gay marriage is measured by respondents' approval or disapproval of the following statement: "homosexuals should be free to get married if they want to". With responses ranging from (1) strongly agree to (5) strongly disagree. These were reversed scored with higher scores displaying a more progressive stance. This survey question is an item of the measurement of conservative family values and an operationalization of attitudes towards the institutionalization of same sex marriage (Kite \& Whitley, 1996). Even though we are aware that this is only a sub-dimension of attitudes towards LGBTs civil rights, this dependent variable provides us with a conservative test since this survey question goes beyond the hypothetical situation of homosexuals should be free to choose the live their own life as they wish (ESS, wave 8). 


\section{Independent Variables}

To examine the acculturation effect, we measured years spent in receiving country ranging from (0) less than a year for the respondents living in the Netherlands and (1) for the respondents living in Denmark, with an upper limit of 30 years to avoid outlier effects. ${ }^{3} \mathrm{We}$ additionally recoded this into categories of five years, to examine the linearity of the effect of the years of residency on the level of acceptance towards gay marriage.

Denomination was captured by the respondents' answers to the survey question if they "belong to any religion or denomination". Respondents could indicate "no", "yes, to Christianity", "yes, to Islam", "yes, to Judaism", or "yes, to another religion/denomination than the ones mentioned". The level of religiosity was measured by asking: "regardless whether you belong to a particular religion or denomination, would you describe yourself as" (1) "not religious at all", (2) "not very religious" (3) "rather religious" or (4) "very religious".

To measure immigrants' level of connection to the home-country we use the degree of connection/belonging to other Turkish/Russian migrants in the receiving country and asked: "[There are] different groups living in the [receiving country]. How strong, would you say, is your sense of belonging to the people from [origin country]?" Respondents were able to answer on a 5-point scale from (1) "not at all" to (5) "very close". Indicating the degree of belonging to/ identification with one's migrant group.

\section{Control Variables}

In the statistical analyses we control for age, measured in years, sex (0 "male" and 1 "female"). Educational level was measured as the highest level of education obtained, including education obtained in the origin country. The responses were converted to the International Standard Classification of Education Scale 1997 [ISCED97] (OECD, European Union, 
UNESCO Institute for Statistics, 2015), with a 7-point scale ranging from (0) "no education" to (6) "second stage of tertiary education". The presence of a stable partner was captured by the respondents' answers to the question "what description applies the best for what their partner does in a regular week".

Those who indicated that they had no partner were coded as the reference category $(0)$ "no partner". Respondents who checked any of the given were coded as (1) "has a partner". To capture employment status we compiled answers to "which description applies the best regarding what you do in a regular week" into three categories: (0) "unemployed" or permanently sick or disabled and not able to work", (1) "in paid work, fulltime" or "part-time", and (2) "other".

\section{Missing Values}

Turkish and Russian respondents in Denmark and the Netherlands with no missing value on the dependent variable ( $97 \%$ of 1,311 respondents, which makes a total of 1,273 ) were included in the analyses. Subsequently, we excluded the respondents who indicated that they belonged to a different denomination than either Islamic (for Turks) or Christianity (for Russians). This means we excluded $4 \%$ of the 400 Turkish-, and $7 \%$ of the 866 Russian respondents. A multiple imputation procedure (Multiple imputation by chained equations [MICE] procedure in StataSE 16) was used to impute values for the respondents who missed values for years spent in receiving country $(<2 \%)$, religiosity $(<1 \%)$, sense of belonging to migrants from origin country (<2\%), age (6\%), sex $(<1 \%)$, educational level $(2 \%)$, partner (<3\%), employment status (4\%) (Lall, 2016; Royston, 2006; Ruben, 1996). ${ }^{5}$ Table A.1 and A.2 in the appendices show the variables' descriptives after multiple imputation, and for each origin country (Klein, 2006). 


\section{Modeling Strategy}

For this paper we used a two-fold modelling strategy in StataSE 16 and applied Ordinary Least Squares (OLS) regression modelling after closely inspecting the distribution of the dependent variable (skewness, kurtosis, and residuals). The first part is concerned with the examination of our more general expectations among the Russian and Turkish samples combined. For the second part, we tested our expectations among the Russian and Turkish immigrants separately.

\section{Results}

Some exploration is needed before we can continue to the testing of our hypotheses. Table 1 shows the results of all migrant groups combined in both countries. First, Model 1 indicates a significant negative effect of length of residence in the host country on migrants' acceptance of gay marriage. However, this effect is still interwoven with cohort- as well as lifecycle effects. We can control for migration cohort (confounding effect) and life cycle-effects by adding the age of the respondents to the model. From Model 2 we can see that by adding respondents' age to the model the significant negative effect of length of stay turns insignificant.

In Model 3 we added several confounding factors. Here we see that a higher level of education is associated with a more progressive stance towards gay marriage, as is being female or employed. With the inclusion of education, the effect of years spent in the host society turns positive. This means that with the added effect of education we take out a bit of the cohort effect that is still in the data, as the new-arrivals are on average higher educated then older migrants. Thus, overall there is a small positive across-the-board effect of length of stay on acceptance of gay marriage.

\section{Religious Connectivity}


With the inclusion of religiosity, the results of Model 4 show that religious migrants, compared to non-religious migrants, are less accepting of gay marriage. In line with previous literature we see here that, regardless of degree of religiosity, Turkish Muslims are on average significantly less accepting of gay marriage $(b=-.920)$ than Russian Christians $(b=-.541)$. The level of religiosity does enhance the negative effect of denomination in a similar way for both groups. What is also interesting in this model is that origin country no longer has an effect when religious items are added to the model, indicating that there is no substantial difference between Russian and Turkish migrants besides religion.

Moving on to the first hypothesis, if we were to see an acculturation effect, the effect of length of stay would be significantly reduced with the inclusion of religion in the model (model 3 to 4). The effect of length of stay is small in itself, and the mediating effect of religiosity on length of stay is minimal to non-existent if we compare the effects of Model 4 with those in Model 3 (change from $b=.014$ to $b=.013$ ). Thus, indicating that norm adaptation does not take substantial forms through lower levels of religiosity (H1a). To extrapolate these different effects to both groups, we modelled our expectations separately for Russians and Turks in Tables $2 \mathrm{a}$ and $2 \mathrm{~b}$, respectively.

The results of Model 1a (in Table 2a) show a positive effect of length of stay among Russian migrants $(b=.020)$, which reduces slightly with the inclusion of religiosity (Model 2a). This suggests a slight acculturation effect among Russian migrants. However, when we test for the strength of this mediation effect, the results show no substantial significance in the change between the two Models. Less than 1 percent of the total effect size of years spent in the receiving country is explained by the mediating effect of religiosity, which is negligible. 
Table 1. OLS regression on acceptance of gay marriage with all immigrants in Denmark and the Netherlands

\begin{tabular}{|c|c|c|c|c|c|c|c|c|c|c|c|c|}
\hline 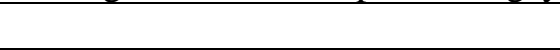 & \multicolumn{3}{|c|}{ Model 1} & \multicolumn{3}{|c|}{ Model 2} & \multicolumn{3}{|c|}{ Model 3} & \multicolumn{3}{|c|}{ Model 4} \\
\hline & $\mathrm{b}$ & $\mathrm{se}$ & sig & $\mathrm{b}$ & $\mathrm{se}$ & sig & $\mathrm{b}$ & se & sig & $\mathrm{b}$ & se & sig \\
\hline Years spent in receiving country & -.013 & .005 & $* *$ & .009 & .006 & & .014 & .006 & $*$ & .013 & .006 & $*$ \\
\hline \multicolumn{13}{|l|}{ Origin/ destination country } \\
\hline Turkey (ref: Russia) & -.820 & .083 & $* * *$ & -.931 & .085 & $* * *$ & -.531 & .102 & $* * *$ & .155 & .182 & \\
\hline Denmark (ref: NL) & -.152 & .075 & $*$ & -.097 & .075 & & -.123 & .073 & $\sim$ & -.172 & .069 & $*$ \\
\hline \multicolumn{13}{|l|}{ Religiosity } \\
\hline Christian (ref: no denomination) & & & & & & & & & & -.541 & .129 & $* * *$ \\
\hline Islamic (ref: no denomination) & & & & & & & & & & -.920 & .205 & $* * *$ \\
\hline Religiosity (not - very religious) ${ }^{\mathrm{a}}$ & & & & & & & & & & .018 & .113 & \\
\hline Religiosity $^{\text {a }} *$ Christian & & & & & & & & & & -.494 & .133 & $* * *$ \\
\hline Religiosity $^{\text {a }}$ Islam & & & & & & & & & & -.583 & .132 & $* * *$ \\
\hline \multicolumn{13}{|l|}{ Control variables } \\
\hline Age & & & & -.024 & .004 & $* * *$ & -.020 & .004 & $* * *$ & -.019 & .004 & $* * *$ \\
\hline Female (ref. male) & & & & & & & .031 & .084 & & .156 & .079 & $*$ \\
\hline Educational level & & & & & & & .227 & .030 & $* * *$ & .141 & .030 & $* * *$ \\
\hline Partner (ref. no partner) & & & & & & & -.092 & .095 & & -.043 & .089 & \\
\hline Employed status (ref. unemployed) & & & & & & & .195 & .110 & $\sim$ & .117 & .103 & \\
\hline Other status (ref. unemployed) & & & & & & & .096 & .119 & & .041 & .111 & \\
\hline Constant & 3.792 & .066 & $* * *$ & 4.556 & .152 & $* * *$ & 3.289 & .267 & $* * *$ & 3.893 & .276 & $* * *$ \\
\hline$A d j . R^{2}$ & $12.02 \%$ & & & $14.46 \%$ & & & $18.62 \%$ & & & $29.82 \%$ & & \\
\hline $\mathrm{n}$ & 1,191 & & & 1,191 & & & 1,191 & & & 1,191 & & \\
\hline
\end{tabular}

Note: ${ }^{a}$ variable is mean-centered; two-tailed: $\sim \mathrm{p}<.10 ; * \mathrm{p}<.05 ; * * \mathrm{p}<.01 ; * * * \mathrm{p}<.001$.

Source: MIFARE 2018 
Table 2a. OLS regression on acceptance of gay marriage with Russians in Denmark and the Netherlands

\begin{tabular}{|c|c|c|c|c|c|c|c|c|c|c|c|c|c|c|c|}
\hline & \multicolumn{3}{|c|}{ Model 1a } & \multicolumn{3}{|c|}{ Model 2a } & \multicolumn{3}{|c|}{ Model 3a } & \multicolumn{3}{|c|}{ Model 4a } & \multicolumn{3}{|c|}{ Model 5a } \\
\hline & $\mathrm{b}$ & $\mathrm{se}$ & sig & $\mathrm{b}$ & se & $\operatorname{sig}$ & $\mathrm{b}$ & se & sig & $\mathrm{b}$ & se & sig & $\mathrm{b}$ & se & sig \\
\hline Yrs spent in residence country $(\mathrm{rc})^{\mathrm{a}}$ & .020 & .008 & $*$ & .017 & .007 & $*$ & .018 & .007 & $*$ & .019 & .007 & $*$ & .017 & .007 & $*$ \\
\hline Religiosity (not - very religious) ${ }^{\mathrm{a}}$ & & & & -.417 & .051 & $* * *$ & -.393 & .051 & $* * *$ & -.392 & .051 & $* * *$ & -.393 & .051 & $* * *$ \\
\hline Ingroup connection $^{\mathrm{a}}$ & & & & & & & -.115 & .033 & $* * *$ & -.114 & .033 & $* * *$ & -.118 & .033 & $* * *$ \\
\hline $\begin{array}{r}\text { Interaction effects } \\
\text { Religiosity }^{*} \text { yrs spent in } \mathrm{rc}^{\mathrm{a}} \\
\text { Ingroup connection }\end{array}$ & & & & & & & & & & .012 & .007 & & -.004 & .005 & \\
\hline Controls & & & & & & & & & & & & & & & \\
\hline Age $^{\mathrm{a}}$ & -.030 & .005 & $* * *$ & -.028 & .005 & $* * *$ & -.027 & .004 & $* * *$ & -.027 & .004 & $* * *$ & -.027 & .004 & $* * *$ \\
\hline Women (ref: male) & -.037 & .104 & & .103 & .102 & & .107 & .101 & & .115 & .101 & & .106 & .101 & \\
\hline Educational level ${ }^{\mathrm{a}}$ & .205 & .047 & $* * *$ & .162 & .045 & $* * *$ & .184 & .045 & $* * *$ & .186 & .045 & $* * *$ & .182 & .045 & $* * *$ \\
\hline Partner (ref: no partner) & .090 & .105 & & .133 & .101 & & .138 & .100 & $\sim$ & .140 & .100 & & .136 & .100 & \\
\hline Employed (ref: unemp) & .119 & .139 & & .010 & .133 & & -.017 & .133 & & -.004 & .133 & & -.017 & .133 & \\
\hline Other (ref: unemp) & -.062 & .151 & & -.154 & .144 & & -.180 & .144 & & -.164 & .144 & & -.182 & .144 & \\
\hline Denmark (ref. the Netherlands) & -.073 & .082 & & -.076 & .079 & & -.095 & .079 & & -.085 & .079 & & -.099 & .079 & \\
\hline Constant & 3.526 & .163 & $* * *$ & 3.467 & .157 & $* * *$ & 3.495 & .156 & $* * *$ & 3.469 & .157 & $* * *$ & 3.500 & .321 & $* * *$ \\
\hline Adj. R2 & $9.84 \%$ & & & $16.83 \%$ & & & $7.99 \%$ & & & $8.13 \%$ & & & $17.95 \%$ & & \\
\hline
\end{tabular}

Note: ${ }^{a}$ variable is mean-centered; two-tailed: $\sim \mathrm{p}<.10 ; * \mathrm{p}<.05 ; * * \mathrm{p}<.01 ; * * * \mathrm{p}<.001$.

Source: MIFARE 2018 
Table 2b. OLS regression on acceptance of gay marriage with Turkish in Denmark and the Netherlands

\begin{tabular}{|c|c|c|c|c|c|c|c|c|c|c|c|c|c|c|c|}
\hline & \multicolumn{3}{|c|}{ Model 1b } & \multicolumn{3}{|c|}{ Model 2b } & \multicolumn{3}{|c|}{ Model 3b } & \multicolumn{3}{|c|}{ Model 4b } & \multicolumn{3}{|c|}{ Model 5b } \\
\hline & $\mathrm{b}$ & se & sig & $\mathrm{b}$ & se & $\operatorname{sig}$ & $\mathrm{b}$ & se & sig & $\mathrm{b}$ & se & sig & $\mathrm{b}$ & se & sig \\
\hline Yrs spent in residence country (rc) ${ }^{a}$ & -.000 & .011 & & .006 & .010 & & .006 & .010 & & .007 & .010 & & .007 & .010 & \\
\hline Religiosity (not - very religious) ${ }^{\mathrm{a}}$ & & & & -.642 & .066 & $* * *$ & -.603 & .070 & $* * *$ & -.602 & .070 & $* * *$ & -.605 & .070 & $* * *$ \\
\hline Ingroup connection $^{\mathrm{a}}$ & & & & & & & -.105 & .067 & & -.105 & .067 & & -.281 & .136 & $*$ \\
\hline $\begin{array}{c}\text { Interaction effects } \\
\text { Religiosity } * \text { yrs spent in } \mathrm{rc}^{\mathrm{a}} \\
\text { Ingroup connection }{ }^{\mathrm{a}} * \mathrm{yrs}^{\mathrm{a}} \text { spent in } \mathrm{rc}^{\mathrm{a}}\end{array}$ & & & & & & & & & & .008 & .007 & & .010 & .007 & \\
\hline Controls & & & & & & & & & & & & & & & \\
\hline Age $^{a}$ & .010 & .009 & & .005 & .008 & & .005 & .008 & & .005 & .008 & & .004 & .008 & \\
\hline Women (ref: male) & .155 & .148 & & .299 & .132 & $*$ & .306 & .132 & $*$ & .304 & .132 & $*$ & .283 & .133 & $*$ \\
\hline Educational level $^{\mathrm{a}}$ & .288 & .046 & $* * *$ & .177 & .042 & $* * *$ & .171 & .043 & $* * *$ & .170 & .043 & $* * *$ & .164 & .043 & $* * *$ \\
\hline Partner (ref: no partner) & -.548 & .199 & $* *$ & -.462 & .179 & $* *$ & -.437 & .179 & $*$ & -.427 & .179 & $*$ & -.442 & .178 & $* *$ \\
\hline Employed (ref: unemp) & .249 & .181 & & .260 & .166 & & .276 & .167 & & .264 & .167 & & .266 & .167 & \\
\hline Other (ref: unemp) & .287 & .197 & & .333 & .180 & $\sim$ & .373 & .180 & $\sim$ & .313 & .181 & $*$ & .326 & .180 & $\sim$ \\
\hline Denmark (ref. the Netherlands) & -.314 & .150 & $*$ & -.543 & .135 & $* * *$ & -.534 & .135 & $* * *$ & -.540 & .135 & $* * *$ & -.543 & .135 & $* * *$ \\
\hline Constant & 3.025 & .240 & $* * *$ & 2.974 & .218 & $* * *$ & 2.935 & .217 & $* * *$ & 2.939 & .216 & $* * *$ & 2.957 & .216 & $* * *$ \\
\hline Adj. R2 & $12.19 \%$ & & & $30.00 \%$ & & & $30.28 \%$ & & & $30.36 \%$ & & & $30.52 \%$ & & \\
\hline $\mathrm{n}$ & 385 & & & 385 & & & 385 & & & 385 & & & 385 & & \\
\hline
\end{tabular}

Note: ${ }^{a}$ variable is mean-centered; two-tailed: $\mathrm{p}<.10 ; * \mathrm{p}<.05 ; * * \mathrm{p}<.01 ; * * * \mathrm{p}<.001$.

Source: MIFARE 2018 
To delve further into the association between migrants' degree of religiosity and their acceptance of gay marriage, we present Figure 1. Panel a in Figure 1 shows the marginal effects plot of religiosity on acceptance of gay marriage over length of stay among Russian migrants. Here we see that the religiosity effect is only significant in the first decade of residence after which it turns insignificant. This indicates a decoupling, rather than an acculturation effect; and mostly so among the very religious.

Among Turkish migrants (Table 2b) we find no observable acculturation effects, as no significant effect of duration of stay can be found among them in the first place (Model $1 \mathrm{~b}$ till $5 b)$. Hence, there is no indication that the acculturation effect exists, or is bigger in one of the two migrant groups, which does not comply with our expectations (H1b), and notably not even the main effect of length of migration can be found among Turkish first-generation migrants (Table 2b, Model 1b). This suggests attitudinal adaptation does simply not take place at all among first generation Turkish migrants. Running these results for each receiving country separately did not yield any different results.

Next, we examine the decoupling mechanism for both migrant groups. Model 4a (Table 2a, Russians) shows a minor and only borderline significant decoupling effect. The main effect of religiosity $(b=-.392)$ becomes less significant with each additional year in the host country $(b=.012$, one-tailed $\mathrm{p}<.10)$. This indicates that religiosity plays a smaller role for Russian migrants' attitudes towards gay marriage when they are in the host society for 30 years as compared to new-arrivals, which is better showed by the earlier discussed marginal effects plot of Figure 1. 


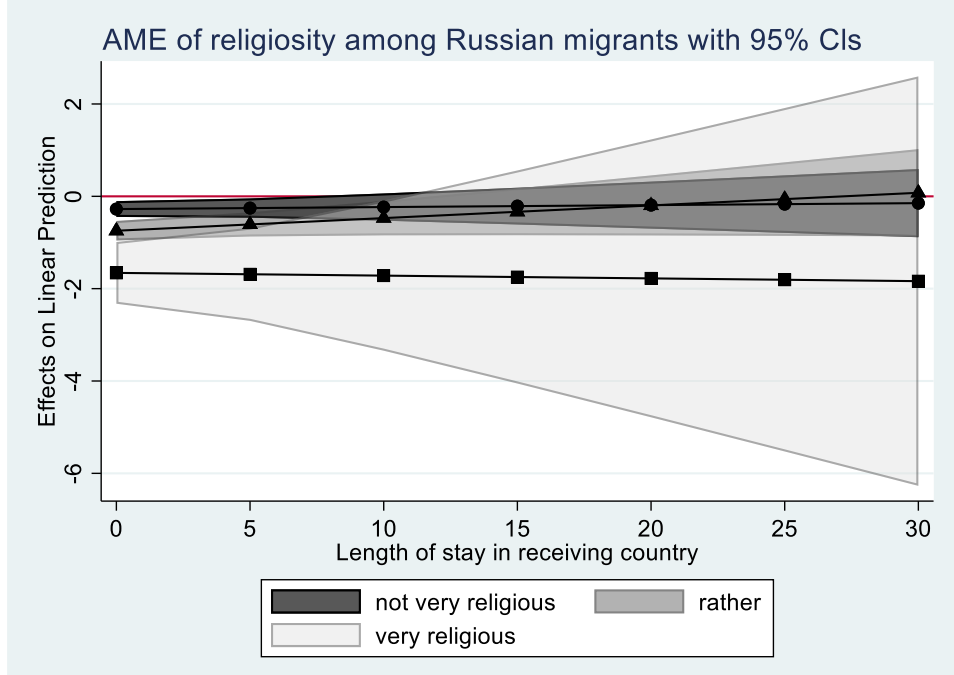

panel a: Russian migrants

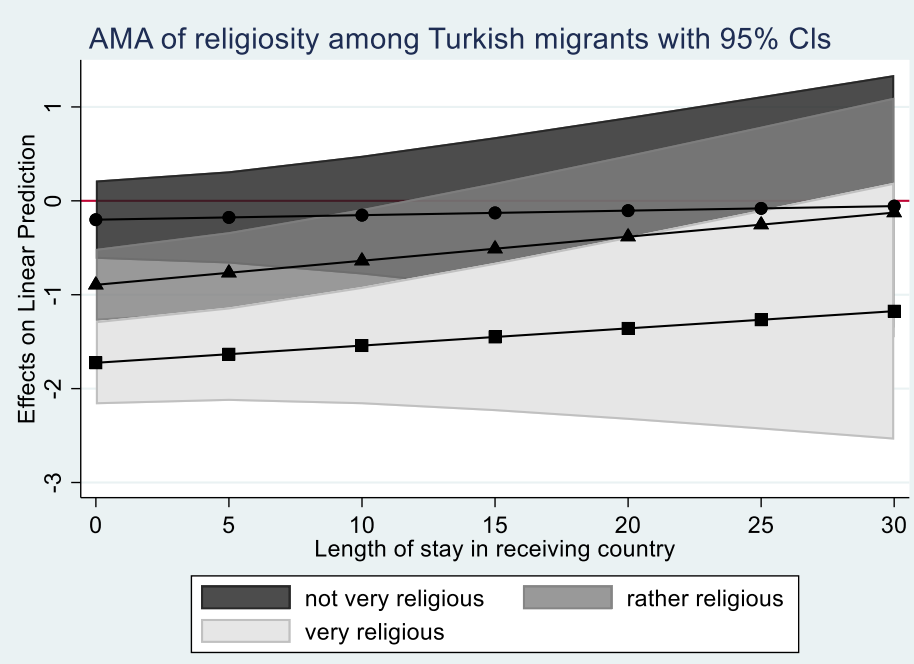

panel b: Turkish migrants

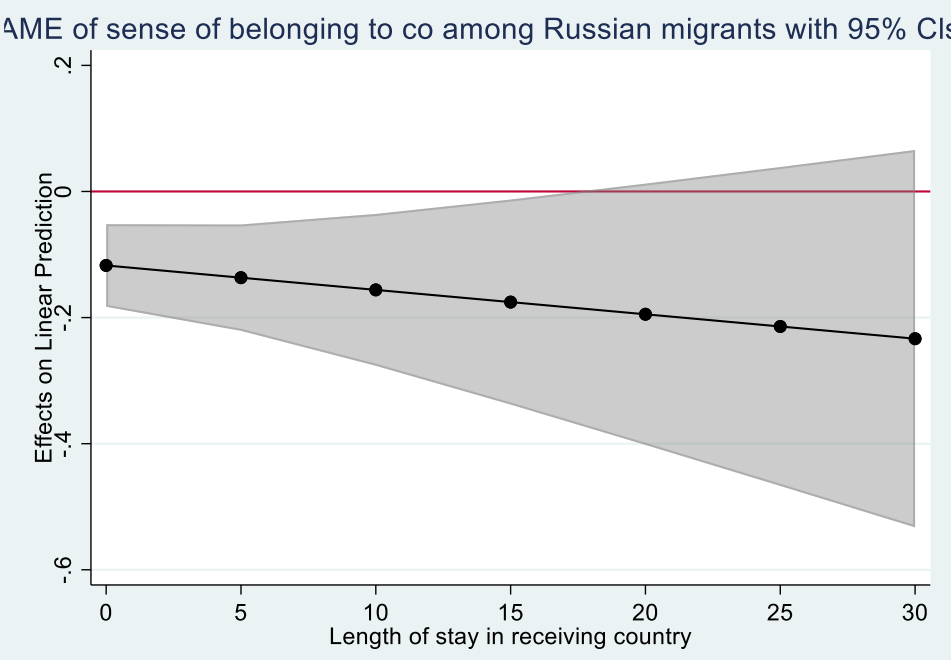

panel c: Russian migrants

AME of sense of belonging to co among Turkish migrants with $95 \% \mathrm{Cls}$

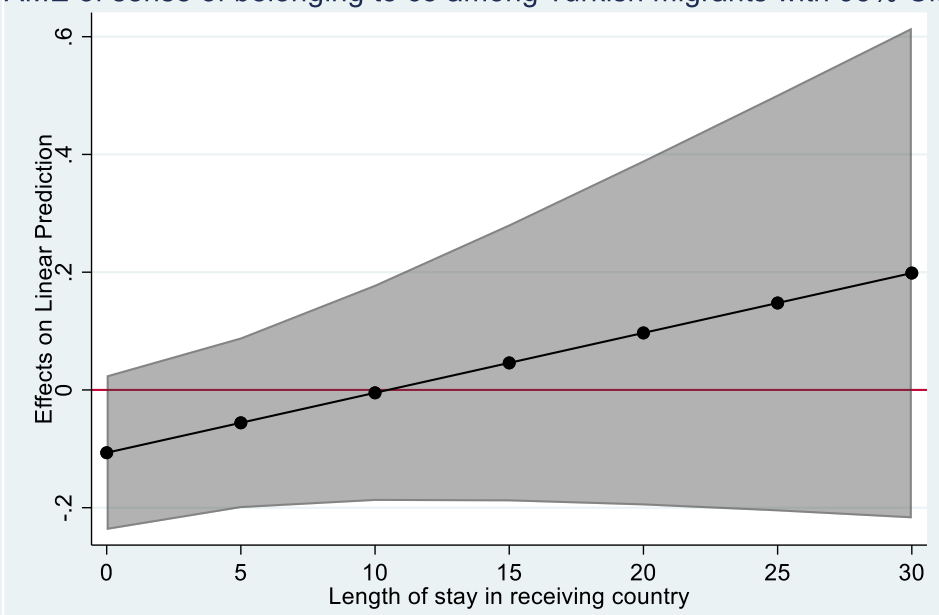

panel d: Turkish migrants 
Among Turks we initially see no support for the expected decoupling effect when we look at the somewhat crude interaction effect in Model 4b (Table 2b). However, when zooming in on the effect by looking at the marginal effects plot in Figure 1, panel b, we see a clear indication that decoupling is taking place among those who are rather religious during the first years after arrival. After about ten to twelve years, religiosity has no significant effect on their attitudes anymore. Among the very religious we see an indication of decoupling after little over 25 years. Whereas, there is no significant effect at all among those who indicate that they are not very religious. This makes sense, as their need to adapt is much smaller.

This means that with our results we find some support for Hypothesis 2a. A marginally significant decoupling effect is shown among Russian migrants, whilst there are structural indications that a decoupling effect is taking place among the rather and very religious Turks. (Robustness checks revealed that here were no indications that there are significant differences between men and women with respect to religious decoupling.) The results indicate that decoupling is taking place more systematically than acculturation among Russian migrants, which support hypothesis $2 \mathrm{~b}$. Furthermore, there is no indication that acculturation is more common among (or visible at all) among Turkish migrants, which goes against our expectation (H2c).

Additionally, Models $1 \mathrm{~b}$ to $5 \mathrm{~b}$ (Table 2b) also show that the Turkish Muslims in Denmark are significantly less accepting of gay marriage than the Turkish Muslims in the Netherlands; and this effect becomes stronger after adding religiosity to the model. In a next step we therefore examined whether there are significant differences in terms of the decoupling effect, for each origin country. For this purpose, we ran Models 4 and 5 while estimating the marginal effect plots separately for both receiving countries (see Tables A.3 and A.4, and Figures A.1 and A.2 in the appendices). For the Turkish Muslims in Denmark, we observe the same patterns as seen in Figure 
1, panels $\mathrm{c}$ and $\mathrm{d}$. The main difference with the Turkish migrants in the Netherlands to those in Denmark is that the decoupling process takes place somewhat faster in the former country. We already see attitudinal adaption among those who are in the Netherlands for five years and so here, the decoupling effect is marginally significant in the cruder regression models as well (final Model of Table A.3).

\section{Ingroup Connectivity}

Continuing to ingroup connectivity as an alternative mechanism for acculturation processes, we see this has a strong main effect on top of religiosity in Model 3a in Table 2a among Russian migrants $(b=-.115)$. Russian migrants with a stronger ingroup connection are less accepting of gay marriage. Russian migrants' ingroup connection also mediates the religiosity effect, but not the effect of length of stay. This indicates that acculturation does not take place through reduced connectivity to other migrants. In addition, we see no decoupling with ingroup connectivity either (Model 5a). Indicating no support for hypothesis $\mathrm{H} 3 \mathrm{a}$ and $\mathrm{H} 3 \mathrm{~b}$ among Russians. But when we look at Turks (Table 2b), we see a marginally significant interaction effect in the expected direction. ${ }^{6}$ Ingroup connectivity has a negative effect on attitudes towards gay marriage $(b=-.281)$ and this effect gets smaller with each year in the receiving country $(b=.010)$.

In sum, we find no significant acculturation effect $(\mathrm{H} 3 \mathrm{a})$ and only a slight indication that decoupling takes place between ingroup connectivity and attitudes based on the norms from the home-country among Turks (H3b). When looking at the marginal effect plots (Figure 1, panel d), we see that this marginal decoupling effect is negligible ${ }^{7}$. Yet, what is of more interest are the different trendlines shown among Russian migrants when sorted by receiving country (Figure A.2 in the appendices). Whereas the Russian migrants in Denmark show the expected decoupling effect 
of home-country connectivity on acceptance of gay marriage to a slight extent, Russian migrants in the Netherlands present an effect in the opposite direction (possibly explaining why no significant interaction effect was found in the regression models). That means that Russian migrants who feel a strong(er) connection to other Russian migrants are likely to show a more conservative stance towards gay marriage with every added year of stay in the Netherlands. However, this effect turns insignificant after approximately 15 years of residence.

\section{Conclusion}

Given recent trends in rising migration, Western-European values are thought to be under pressure (Breidahl \& Larsen, 2016; Dinesen, 2013; Röder \& Mühlau, 2014). Muslim migrants are often given blame, as their values differ substantially from European values (Inglehart, 1997; Shield, 2017; Spierings et al. 2015). Research on the link between Muslim piety and support for Western values such as gay rights, and gender equality has found robust evidence for this thesis and investigated attitude developments due to migration (David \& Greenstein, 2009; Frejka \& Westoff, 2008; Inglehart, 1997; Norris \& Inglehart, 2012; Röder \& Lubbers, 2015). However, although Muslims are the most problematized migrant group, these linkages and the mechanisms of acculturation need not be exclusive to Muslim migrants only.

With this study we broadened the focus in the literature by comparing Muslim migrants to Russian Christian (Orthodox) migrants to answer the question: whether and to what extent does migration affect the relationship between religious-/ ingroup connectivity and attitudes towards gay marriage? In line with previous studies, we investigated acculturation and decoupling processes, whilst we extended the work on this issue by not only focusing on these processes with regard to religious-, but also with regard to social identification. Our findings indicated interesting 
similarities as well as some noteworthy differences between the migrant groups which we will reflect on below.

Regarding religiosity we found a significant effect of Muslim and Christian piety. Yet, Muslims showed to have slightly more restrictive attitudes towards gay marriage in line with our expectation and previous literature on this matter (Alexander \& Welzel, 2011). A more surprising finding was the absence of a main effect of migration length of stay among Turkish migrants. While previous research among Turkish migrants on the topic also showed that attitudinal change happens over generations (Van Klingeren \& Spierings, 2020), it apparently does not necessarily change within the first generation. Or at least, the changes are not large (or fast) enough to be substantial, and therefore they do not show in our regression models. However, Russians differed from Turks, because we did see a significant effect of length of stay within this group. This was however not be explained by a reduced level of religiosity. Different patterns were found with regard to the decoupling thesis, for which we did found some evidence among both Turkish Muslim and Russian (Orthodox-)Christian migrants. Albeit the process appears to happen much faster among Turkish migrants in the Netherlands, and to a lesser extent among Turkish migrants in Denmark and Russian migrants.

These findings indicate that religiosity remains an important part of the identity of both migrant groups in the receiving country, but the related attitudes are indeed flexible. The fact that decoupling takes place after fewer years among Russian migrants may also be due to their starting point, which diverges somewhat less from the average host-country attitudes. These findings provide support for the social mobility thesis of the Social Identity Theory, which suggests that people are willing to adapt in order to belong to, or be part of the majority group, yet are hesitant 
to leave their initial social group entirely. Hence, by maintaining religious while adapting their attitudes they can achieve both.

What is interesting, however, is that this last strategy is thus not limited to Muslim migrants, but extents along other religious migrant groups as well. And, since Russian migrants came to the receiving countries in smaller numbers, the necessity to connect and adapt to the receiving country is much higher within this group. Subsequently, the results showing that adaptation happens much faster within this group is not very surprising either. This means the focus on Muslim migrants in the public debate makes sense not only because it is a much larger group, with a different dominant religion that is more visible to the majority's eye than is the Russian (Orthodox) Christian church, but also since the attitudinal adaptation by Muslim migrants takes longer and diverges more from the general population to begin with.

An additional innovative finding is that there was no convincing acculturation, or decoupling effect with ingroup connectivity for either migrant group. Even though migrants' connectivity to their origin country members had a strong effect on attitudes towards gay marriage, and it mediated a minor part of the religiosity effect among Turks. This aspect of one's identity does not completely overlap with religiousness. Contrary to our expectations, we found a more distinct difference between Russian migrants in the Netherlands in duration of stay than in Denmark in relation to the association between ingroup connectivity and acceptance of gay marriage. Giving the indication that first-generation Russian migrants do not easily lose connection with their home country members in every receiving country, and that the relation between ingroup connectivity and home-country related attitudes do remain strong and, in some cases, even strengthen in time. Though we cannot empirically explain the found differences between receiving countries, we can speculate that there is a difference in isolation of these migrant groups, or that 
there is an unexplained variance between perceived or actual discrimination towards Russian migrants. Further research could usefully explore how these two factors affect Russian migrants' adaptation processes.

In sum we can state that although the strength of the effects and significance levels differed somewhat between the two migrant groups, aside from the previously discussed finding, the overall direction of the effects and conclusions did not. Generally, we can say that the starting point among first generation Muslim migrants is more conservative than among Christian Russian migrants and that for the former group it takes somewhat more time to adapt, but the decoupling patterns with regard to religiosity are similar, nonetheless.

Despite this study's clear contributions to the literature and our understanding of acculturation processes among first-generation migrants in Europe. There are also some minor drawbacks which we wish to address here. First previous research has found a differential impact of individual- versus communal types of religiosity (Alexander \& Welzel, 2011; Glas et al., 2018; Spierings, 2018). Something we were unable to do in this paper. Therefore, future research could invest in establishing an even more nuanced picture in this regard. Furthermore, though we addressed this issue, our otherwise unique dataset can never fully control for cohort or period effects due to the cross-sectional nature of the data. Nevertheless, given that one would expect older migrants to be more religious, the migration duration and decoupling effects are more likely to present an underestimation of the true results than an overestimation. Thereby making our tests quite rigorous and our findings more trustworthy.

Finally, in the end we are able to provide unique insights about acculturation patterns among two first-generation migrant groups, which show surprisingly similar patterns especially given that there are obvious differences between the two groups. There is still much to explore in 
this regard, as there are many more migrant groups within Europe that merit their own research projects, we have taken a first and important step in studying acculturation and decoupling processes beyond the Muslim migrant group, and beyond religious identification. This provides us with crucial information of what else might be going on regarding the integration processes of migrants to Western Europe.

\section{Footnotes}

\footnotetext{
${ }^{1}$ The data was also collected in Germany. Nevertheless, given a very particular history of the Russian migrant group in Germany (Aussiedler), this group is incompatible with Russian migrants in Denmark and the Netherlands. Thus, we excluded Germany from this study.

${ }^{2}$ To deal with this difference we have combined those who indicated that they were in the Netherlands for less than a year with those who were there for a year. The differences between these groups were negligible.

${ }^{3} 0.05 \%$ has indicated that they lived in the receiving country for more than 30 years.

${ }^{4} \mathrm{~A}$ small number of respondents indicated that they were not affiliated to any particular denomination, yet they did indicate some degree of religiosity. These were set to 1 (not religious at all), given that they are not religious in the traditional sense as we study in this paper.

${ }^{5}$ To assist the procedure (MICE), the values were imputed before excluding the respondents on the various denomination categories $(n=1,273)$. Furthermore, we added respondents' sense of belonging to the people from the receiving country and migrants in general, and respondents' agreeability with the statement if they can get ahead in the receiving country's society.

${ }^{6}$ Please note that this is by means of a one-tailed significance test since we formulated a one direction-expectation.

${ }^{7}$ These effects did not differ between Denmark and the Netherlands (see Figure A.2 in the appendices).
}

\section{References}

Adamczyk, A. \& Pitt, C. (2009). Shaping attitudes about homosexuality: The role of religion and cultural context. Social Science Research, 38(2), 338-351.

Alba, R.D. \& Nee, V. (2003). Remaking the American Mainstream: Assimilation and contemporary immigration. Remaking the American Mainstream. Cambridge (MA): Harvard University Press.

Alesina, A., Baqir, R. \& Easterly, W. (1999). Public goods and ethnic division. The Quaterly Journal of Economics, 114(4), 1243-1284.

Alexander, A.C. \& Welzel, C. (2011). Islam and patriarchy: How robust is muslim support for patriarchal values? International Review of Sociology, 21(2), 249-276. 
Anderson, J. \& Koc, Y. (2015). Exploring patterns of explicit and implicit anti-gay attitudes in Muslims and Atheists. European Journal of Social Psychology, 45(6), 687-701.

Barlas, A. (2002). Believing women in Islam: Unreading patriarchal interpretations of the Qur'an. Austin (TX): University of Texas Press.

Bekhuis, H. \& Hedegaard, T.F. (2018). Design and content of the MIFARE Study. Methodological Research Report. Nijmegen.

Bekhuis, H., Fage Hedegaard, T.F., Seibel, V., Degen, D. \& Renema, J. (2018). MIFARE study - Migrants' welfare state attitudes [Dataset]. DANS (Data Archiving and Network Services). KNAW.

Berkhout, J. \& Sudulich, M.L. (2011). Demographics of immigration: the Netherlands. SOM Working Paper No. 2011-07, available from: http://ssrn.com/abstract1/41990213.

Berry, J.W. (1980). Acculturation as varieties of adaptation. In A.M. Padilla (Ed) Acculturation: Theory, models and findings. Boulder (CO): Westview Press.

Borjas, G.J. (1987). Self-selection and the earnings of immigrants. The American Economic Review, 77(4), 531-553.

Breidahl, K.N. \& Larsen, C.A. (2016). The myth of unadaptable gender roles: Attitudes towards women's paid work among immigrants across 30 European countries. Journal of European Social Policy, 26(5), 387-401.

Castles, S. (2006). Guestworkers in Europe: A resurrection? International Migration Review, 40(4), 741766.

Castles, S. (2010). Understanding global migration: A social transformation perspective. Journal of Ethnic and Migration Studies, 36(10), 1565-1586.

Castles, S. (2017). Migration and Community Formation under Conditions of Globalization. In Migration, Citizenship and Identity, edited by S. Castles. Cheltenham, UK: Edward Elgar Publishing.

Cesur, S.N., Hanquinet, L. \& Duru, D.N. (2018). The "European Turks": identities of high-skilled Turkish migrants in Europe, Southeast European and Black Sea Studies, 18(1), 127-144.

Cochrane, C. (2013). The effects of Islam, religiosity, and socialization on Muslim-Canadian opinions about same-sex marriage. Comparative Migration Studies, 1, 147-178.

David, S. \& Greenstein, T. (2009). Gender Ideology: Components, Predictors, and Consequences. Annual Review of Sociology, 35, 172-193.

Diehl, C., Koenig, M. \& Ruckdeschel, K. (2009). Religiosity and gender equality: Comparing natives and Muslim migrants in Germany. Ethnic and Racial Studies, 32(2), 278-301.

Dinesen, P.T. (2013). Where you come from or where you live? Examining the cultural and institutional 
explanation of generalized trust using migration as a natural experiment. European Sociological Review, 29(1), 114-128.

Evans, G. \& Northmore-Ball, K. (2012). The limits of secularization? The resurgence of orthodoxy in postSoviet Russia. Journal for the Scientific Study of Religion, 51(4), 195-808.

Frejka, T., \& Westoff, C. (2008). Religion, religiousness and fertility in the US and in Europe. European Journal of Population/Revue européenne de Démographie, 24(1), 5-31.

Glas, S., Spierings, N. \& Scheepers, P. (2018). Re-Understanding Religion and Support for Gender Equality in Arab Countries. Gender and Society, 32(5): 686-712.

Güngor, D, Bornstein, M.H. \& Phalet, K. (2012). Religiosity, Values, and Acculturation: A Study of Turkish, Turkish Belgian, and Belgian Adolescents. International Journal of Behavioral Development, 36(5), 367-373.

Inglehart, R. (1997). Modernization and postmodernization: Cultural, economic, and political change in 43 societies. Princeton (NJ): Princeton University Press.

IPSOS (2016). Religion. Retrieved from: www.ipsosglobaltrends.com/religion/.

International Social Survey Programme. (1991). Religion I - ZA no. 2150. GESIS. DOI:10.4232/1.2150.

International Social Survey Programme. (1998). Religion II - ZA no. 3190. GESIS. DOI:10.4232/1.3190

International Social Survey Programme. (2008). Religion III - ZA no. 4950. GESIS. DOI: 10.4232/1.13161.

Jensen, K., Nielsen, J.H., Brænder, M., Mouritsen, P. \& Olsen, T.V. (2010). Tolerance and Cultural Diversity Discourses in Denmark [Accept Pluralism Working Paper 7/ 2010]. European University Institute Robert Schuman Centre for Advanced Studies.

Kashyap, R., \& Lewis, V.A. (2013). British Muslim youth and religious fundamentalism: A quantitative investigation. Ethnic and Racial Studies, 36(12), 2117-2140.

Kopnina, H. (2005). East to West migration: Russian migrants in Western Europe. Aldershot, UK: Ashgate Publishing Company.

Klor, E. \& Shayo, M. (2010). Social identity and preferences over redistribution. Journal of Public Economics, 94(3-4), 269-278.

Liebig, T. (2007). The labour market integration of immigrants in Denmark [OECD Social, Employment and Migration Working Papers, March 2007]. Organisation for Economic Co-operation and Development.

Maliepaard, M., Lubbers, M. \& Gijsberts, M. (2010). Generational differences in ethnic and religious attachment and their interrelation: A study among Muslim minorities in the Netherlands. Ethnic and Racial Studies, 33(3), 451-472. 
Norris, P., \& Inglehart, R.F. (2012). Muslim Integration into Western Cultures: Between Origins and Destinations. Political Studies, 60(2), 228-251.

Pew Research Center. (2018). Attending religious services "seldom" or "never" is the norm in Western Europe. Retrieved from www.pewforum.org/2018/05/29/religious-practice-and-belief/pf_05-2918_religion-western-europe-03-00/.

Phinney, J.S. (1990). Ethnic identity in adolescents and adults: Review of research. Psychological Bulletin, 108(3), 499-514.

Renema, J.A.J. \& Lubbers, M. (2019). Welfare-Based Income among Immigrants in the Netherlands: Differences in Social and Human Capital. Journal of Immigrant and Refugee Studies, 17(2), 128151.

Röder, A. (2015). Immigrants’ Attitudes toward Homosexuality: Socialization, Religion, and Acculturation in European Host Societies. International Migration Review, 49(4), 1042-1070.

Röder, A., \& Lubbers, M. (2015). Attitudes towards Homosexuality amongst Recent Polish Migrants in Western Europe: Migrant Selectivity and Attitude Change. Journal of Ethnic and Migration Studies, 41(11), 1858-1884.

Röder, A. \& Lubbers, M. (2016). After migration: Acculturation of attitudes towards homosexuality among Polish immigrants in Germany, Ireland, the Netherlands and the UK. Ethnicities, 16(2), 261-289.

Röder, A. \& Mühlau, P. (2014). Are they acculturating? Europe's immigrants and gender egalitarianism. Social Forces, 92(3), 899-928.

Roggemans, L., Spruyt, B., Van Droogenbroeck, F. \& Keppens, G. (2015). Religion and Negative Attitudes towards Homosexuals: An Analysis of Urban Young People and Their Attitudes towards Homosexuality. Young, 23(3), 254-276.

Shield, A.D.J. (2017). Immigrants in the Sexual Revolution. Perceptions and Participation in Northwest Europe. London, UK: Palgrave Macmillan.

Sears, D.O. \& Levy, S. (2003). Childhood and adult political development. In Oxford handbook of political psychology, edited by D. O. Sears, L. Huddy and R. Jervis. New York (NY): Oxford University Press.

Sinelina, Y. (2015). The dynamics of Orthodox and Muslim religiosity in Russia, 1989-2012. Religion, State and Society, 43(3), 292-308.

Staring, R. (1999). Migratiescenario's. In De Ongekende Stad 1: Overkomst en Verblijf van Vreemdelingen in Rotterdam, edited by J.Burgers and G.Engbersen. Amsterdam: Boom.

Statistics Denmark. (2017). Population and elections. Retrieved from: www.statbank.dk/10024.

Statistics Netherlands. (2018). Population by migration background; sex, age, January 1. Retrieved from: 
https://opendata.cbs.nl/statline/\#/CBS/nl/dataset/70787ned/table?ts=1559655622019.

Soehl, T. (2017). From origins to destinations: acculturation trajectories in migrants' attitudes towards homosexuality. Journal of Ethnic and Migration Studies, 43(11), 1831-1853.

Spierings, N., Zaslove, A., Mügge, L. \& De Lange, S. (2015). Gender and Populist Radical-Right Politics: An Introduction. Patterns of Prejudice, 41(5), 749-771.

Thornton, A., Alwin, D.F., \& Camburn, D. (1983). Causes and Consequences of Sex-Role Attitudes and Attitude Change. American Sociological Review, 48(2), 211-227.

Upadhyah, A. (2016). Religion and religiosity in Russia: An overview. International Studies, 53(3-4), 195209.

Van Den Akker, H., Van Der Ploeg, R., \& Scheepers, P. (2013). Disapproval of homosexuality: Comparative research on individual and national determinants of disapproval of homosexuality in 20 European countries. International Journal of Public Opinion Research, 25(1), 64-86.

Van Klingeren, M \& Spierings, N. (2020). Acculturation, Decoupling, or Both? Migration's Impact on the Linkage between Religiosity and Gender Equality Attitudes. Journal of Ethnic and Migration Studies, 46(15), 3079-3100.

Van Tubergen, F., \& Sindradóttir, J.Í. (2011). The Religiosity of Immigrants in Europe: A Cross-National Study. Journal for the Scientific Study of Religion, 50(2), 272-288.

Verkuyten, M. \& Martinovic, B. (2012). Immigrants' National Identification: Meanings, Determinants, and Consequences. Social Issues and Policy Review, 6(1), 82-112.

Willet, G.A. (2007). Crisis of Self and Other: Russian-speaking migrants in the Netherlands and European Union [PhD dissertation]. The University of Iowa.

Wimmer, A. (2008). The making and unmaking of ethnic boundaries: A multilevel process theory. American Journal of Sociology, 113(4): 970-1022. 


\section{Appendices}

$\underline{\text { Table A.1. Descriptive statistics }}$

\begin{tabular}{rrrrr}
\hline & Total & \multicolumn{2}{c}{ Range } \\
\hline & mean & s.d. & min & max \\
\hline Acceptance of gay marriage & 3.293 & 1.302 & 1 & 5 \\
Years spent in receiving country & 12.265 & 8.277 & 0 & 30 \\
Religiosity & 2.186 & 0.918 & 1 & 4 \\
Age & 42.036 & 11.206 & 18 & 75 \\
Sense of connection to migrants from origin country & 3.272 & 148 & 1 & 5 \\
Educational level & 4.047 & 1.454 & 0 & 6 \\
Female (ref: male) & 0.727 & 0.445 & 0 & 1 \\
Partner (ref: no partner) & 0.832 & 0.374 & 0 & 1 \\
& & & & \\
No denomination & $26 \%$ & & & \\
Christian & $45 \%$ & & & \\
Islamic & $28 \%$ & & & \\
Male & $27 \%$ & & & \\
Female & $73 \%$ & & \\
No partner & $17 \%$ & & \\
Partner & $83 \%$ & & \\
Enemployed/unable to be employed & $14 \%$ & & \\
Employed & $59 \%$ & & \\
Other & $27 \%$ & &
\end{tabular}

$\mathrm{n}=1,191$

Source: MIFARE 2018 
Table A.2. Descriptive statistics by origin country

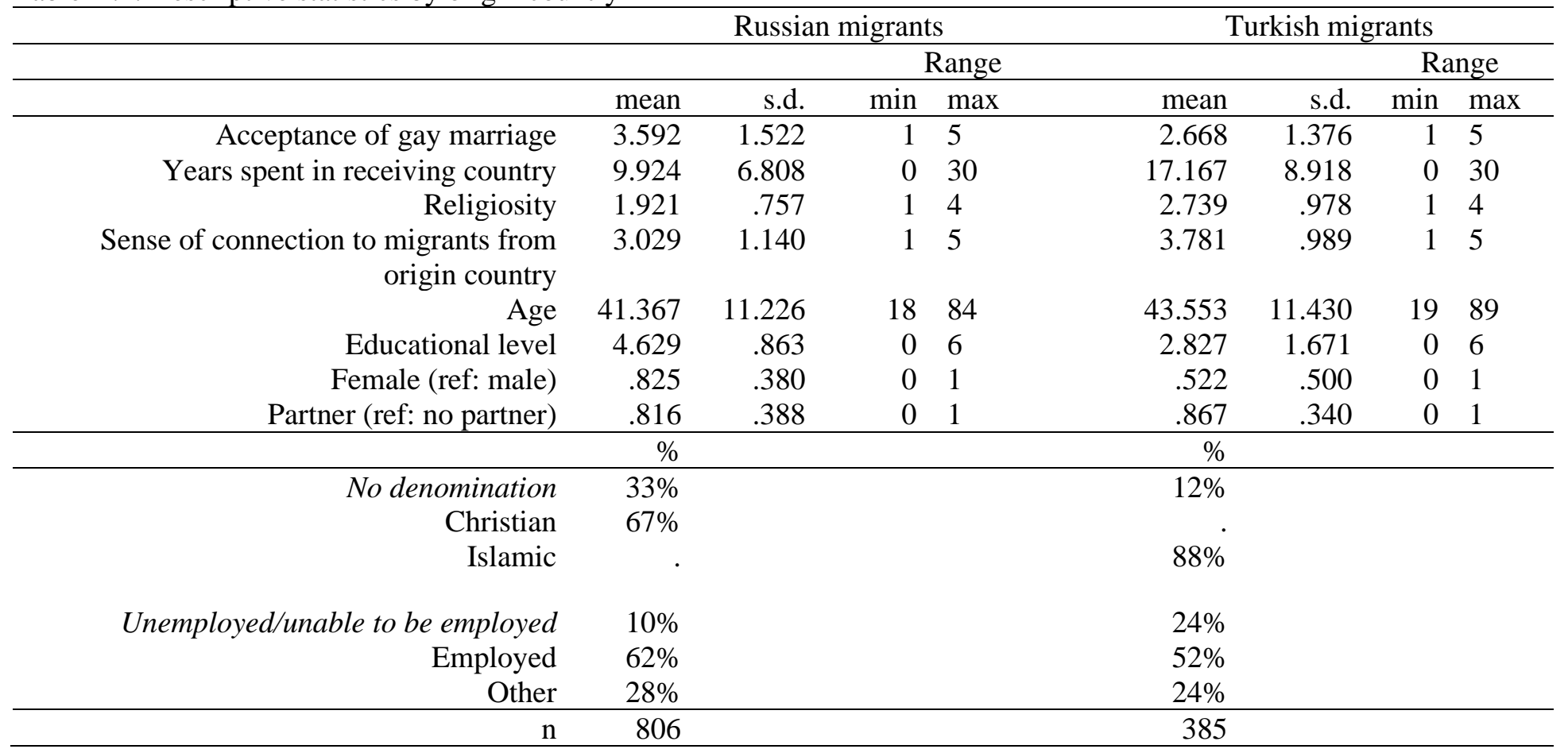

Source: MIFARE 2018 
Table A.3. OLS regression on acceptance of gay marriage by origin country and by receiving country, model 4

\begin{tabular}{|c|c|c|c|c|c|c|c|c|c|c|c|c|}
\hline & \multicolumn{3}{|c|}{$\begin{array}{l}\text { Russian migrants in } \\
\text { Denmark }\end{array}$} & \multicolumn{3}{|c|}{$\begin{array}{l}\text { Russian migrants in the } \\
\text { Netherlands }\end{array}$} & \multicolumn{3}{|c|}{$\begin{array}{l}\text { Turkish migrants in } \\
\text { Denmark }\end{array}$} & \multicolumn{3}{|c|}{$\begin{array}{l}\text { Turkish migrants in the } \\
\text { Netherlands }\end{array}$} \\
\hline & $\mathrm{b}$ & se & sig & $\mathrm{b}$ & se & sig & $\mathrm{b}$ & se & sig & $\mathrm{b}$ & se & sig \\
\hline Years spent in residence country ${ }^{\mathrm{a}}(\mathrm{rc})$ & .026 & .011 & & .011 & .010 & & .024 & .030 & & -.003 & .014 & \\
\hline Religiosity (not - very religious) ${ }^{a}$ & -.419 & .081 & $* * *$ & -.387 & .065 & $* * *$ & -.710 & .104 & $* * *$ & -.472 & .099 & $* * *$ \\
\hline $\begin{array}{r}\text { Sense of connection to migrants from } \\
\text { origin country }\end{array}$ & -.103 & .051 & $*$ & -.099 & .044 & $*$ & -.117 & .098 & & -.087 & .091 & \\
\hline \multicolumn{13}{|l|}{ Interaction effects } \\
\hline \multicolumn{13}{|l|}{ Controls } \\
\hline Age & -.033 & .007 & **** & -.023 & .007 & $* * *$ & -.002 & .023 & & .003 & .012 & \\
\hline Women (ref: male) & .144 & .161 & & .111 & .130 & & .419 & .181 & * & .080 & .204 & \\
\hline Educational level & 197 & .065 & *** & .073 & .063 & & .140 & .062 & * & .191 & 058 & $* * *$ \\
\hline Partner (ref: no partner) & .060 & .155 & & .177 & 128 & & -.375 & 257 & & -.417 & 263 & \\
\hline Employed (ref: unemp) & .093 & 198 & & -.057 & 178 & & -.187 & 246 & & .230 & 230 & \\
\hline Other (ref: unemp) & -.009 & 222 & & -.259 & 189 & & -.116 & 268 & & .435 & 251 & \\
\hline Constant & 3.662 & .507 & $* * *$ & 4.414 & .430 & $* * *$ & 4.306 & .855 & $* * *$ & 2.548 & .732 & $* * *$ \\
\hline Adj. $R 2$ & $20.41 \%$ & & & $15.10 \%$ & & & $31.46 \%$ & & & $27.98 \%$ & & \\
\hline $\mathrm{n}$ & 367 & & & 439 & & & 197 & & & 188 & & \\
\hline
\end{tabular}

Note: ${ }^{a}$ variable is mean-centered (interaction effect); two-tailed: p<.10; * $\mathrm{p}<.05 ; * * \mathrm{p}<.01 ; * * * \mathrm{p}<.001$.

Source: MIFARE 2018 
Table A.4. OLS regression on acceptance of gay marriage by origin country and by receiving country, model 5

\begin{tabular}{|c|c|c|c|c|c|c|c|c|c|c|c|c|}
\hline & \multicolumn{3}{|c|}{$\begin{array}{l}\text { Russian migrants in } \\
\text { Denmark }\end{array}$} & \multicolumn{3}{|c|}{$\begin{array}{l}\text { Russian migrants in the } \\
\text { Netherlands }\end{array}$} & \multicolumn{3}{|c|}{$\begin{array}{l}\text { Turkish migrants in } \\
\text { Denmark }\end{array}$} & \multicolumn{3}{|c|}{$\begin{array}{l}\text { Turkish migrants in the } \\
\text { Netherlands }\end{array}$} \\
\hline & $\mathrm{b}$ & se & sig & $\mathrm{b}$ & se & sig & $\mathrm{b}$ & se & sig & $\mathrm{b}$ & se & sig \\
\hline Years spent in residence country ${ }^{\mathrm{a}}(\mathrm{rc})$ & .026 & .011 & $*$ & .011 & .010 & & .016 & .015 & & -.003 & .014 & \\
\hline Religiosity (not - very religious) & -.422 & .081 & $* * *$ & -.382 & .065 & $* * *$ & -.690 & .103 & $* * *$ & -.492 & .098 & $* * *$ \\
\hline $\begin{array}{r}\text { Sense of connection to migrants from } \\
\text { origin country }\end{array}$ & -.102 & .051 & $*$ & -.109 & .044 & $*$ & -.128 & .098 & & -.097 & .092 & \\
\hline \multicolumn{13}{|l|}{ Interaction effects } \\
\hline \multicolumn{13}{|l|}{ Controls } \\
\hline Age & -.033 & .007 & **** & -.023 & .006 & $* * *$ & -.002 & .012 & & -.000 & .012 & \\
\hline Women (ref: male) & .142 & .161 & & .108 & .130 & & .411 & .182 & $*$ & .040 & .204 & \\
\hline Educational level & 197 & .066 & *** & .067 & .063 & & 138 & .062 & * & .179 & .059 & ** \\
\hline Partner (ref: no partner) & .060 & 154 & & .163 & 128 & & .357 & .256 & & 490 & 264 & $\sim$ \\
\hline Employed (ref: unemp) & .089 & 196 & & -.036 & 178 & & -.200 & 242 & & .251 & 231 & \\
\hline Other (ref: unemp) & -.001 & 222 & & -.254 & 189 & & -.131 & .265 & & .515 & 247 & \\
\hline Constant & 3.662 & .507 & $* * *$ & 4.414 & .430 & $* * *$ & 3.772 & .843 & $* * *$ & 3.861 & .690 & $* * *$ \\
\hline Adj. $R 2$ & $20.41 \%$ & & & $14.64 \%$ & & & $31.47 \%$ & & & $27.55 \%$ & & \\
\hline $\mathrm{n}$ & 367 & & & 439 & & & 197 & & & 188 & & \\
\hline
\end{tabular}

Note: ${ }^{a}$ variable is mean-centered (interaction effect); two-tailed: $\sim \mathrm{p}<.10 ; * \mathrm{p}<.05 ; * * \mathrm{p}<.01 ; * * * \mathrm{p}<.001$.

Source: MIFARE 2018 


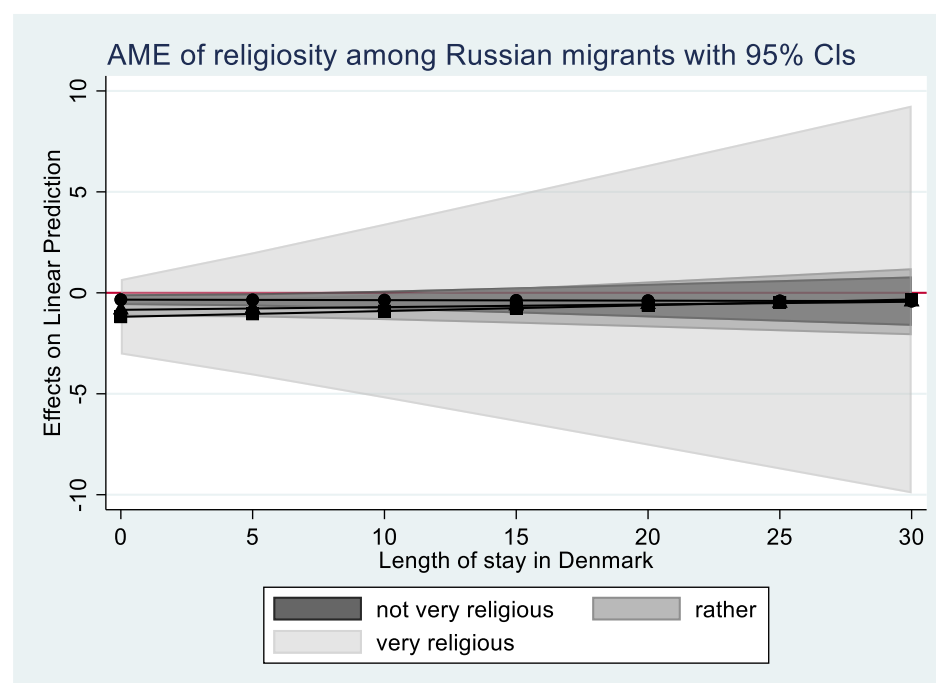

panel a: Russian migrants in Denmark

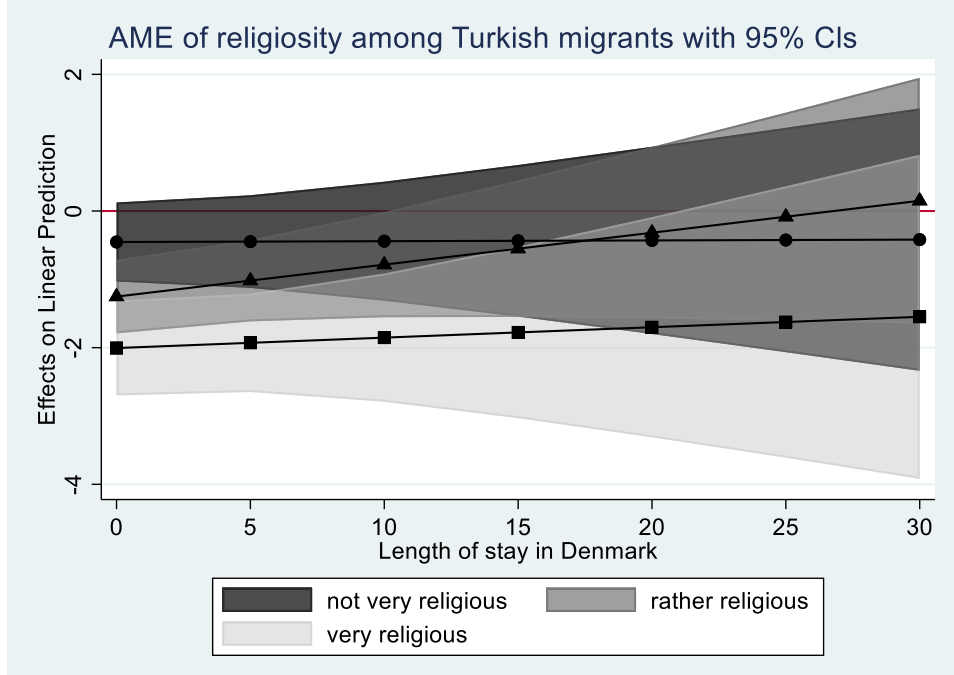

panel c: Turkish migrants in Denmark

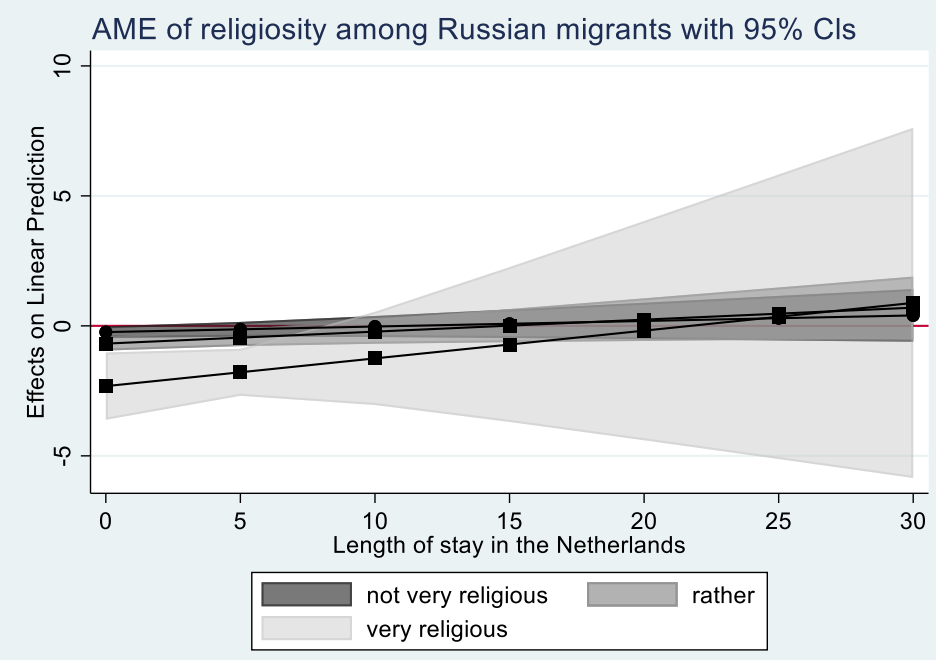

panel b: Russian migrants in the Netherlands

AME of religiosity among Turkish migrants with $95 \% \mathrm{Cls}$

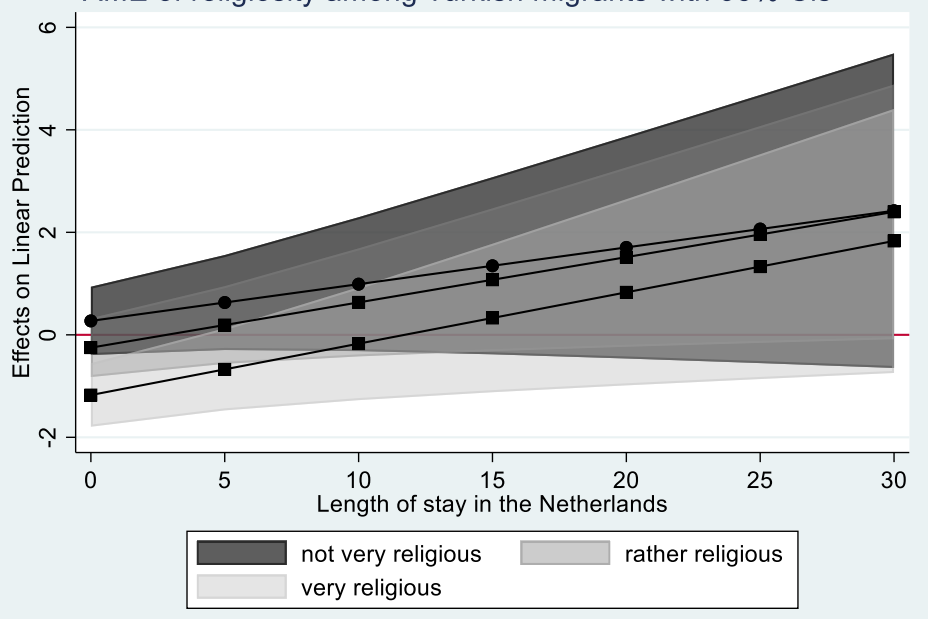

panel d: Turkish migrants in the Netherlands

Figure A.1. Average Marginal Effects (AME) of acculturation effect on the association between religiosity and acceptance of gay marriage per origin- and receiving country 


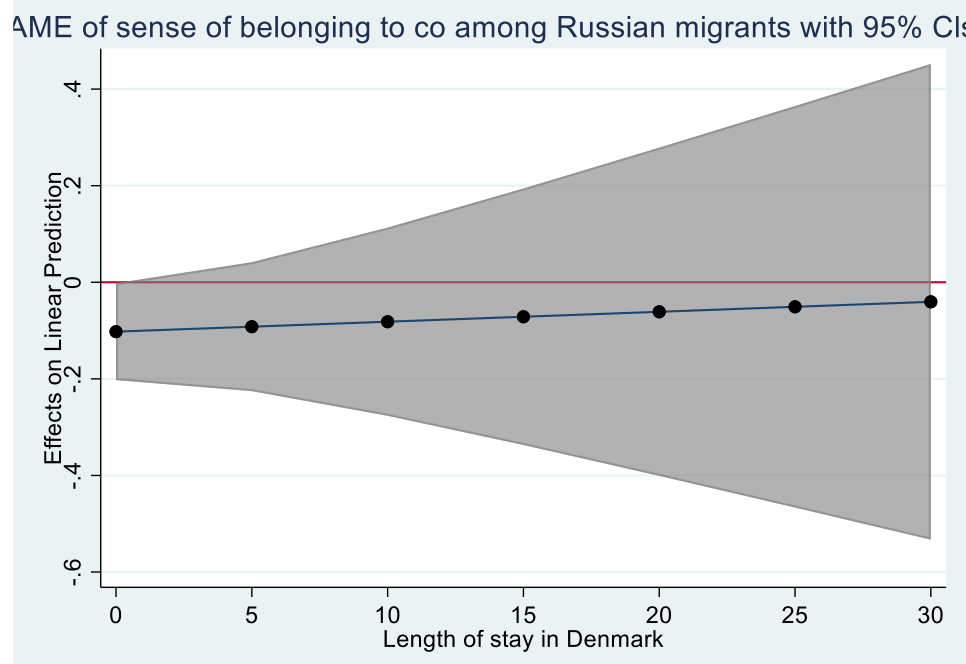

panel a: Russian migrants in Denmark

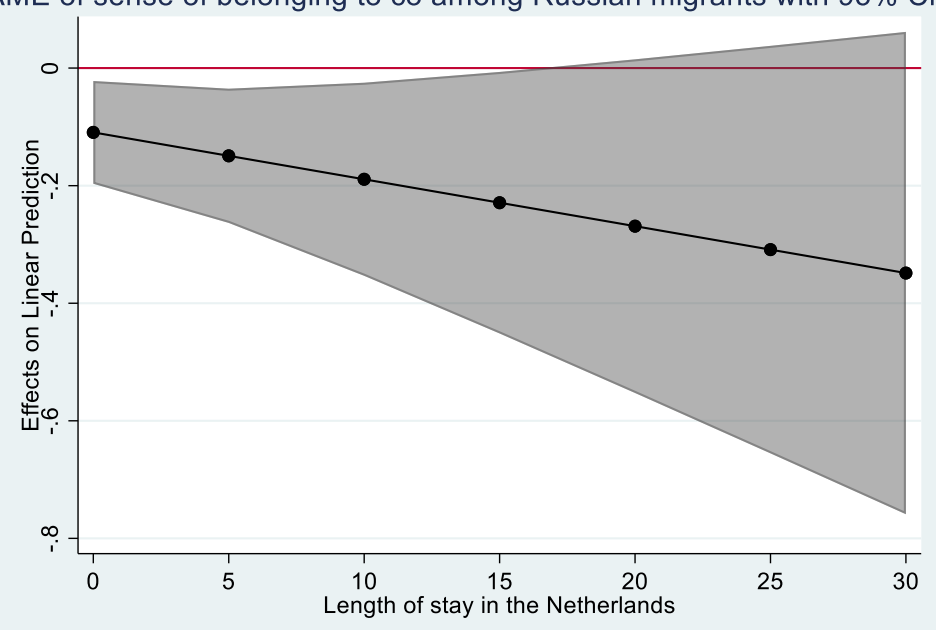

panel b: Russian migrants in the Netherlands

AME of sense of belonging to co among Turkish migrants with $95 \%$ ClsAME of sense of belonging to co among Turkish migrants with $95 \%$ Cls

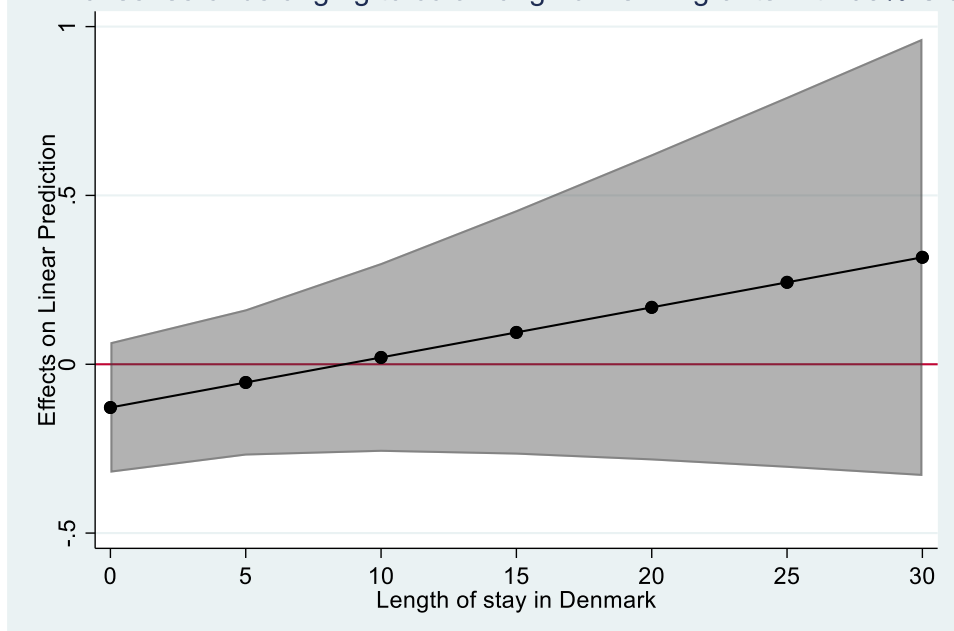

panel c: Turkish migrants in Denmark

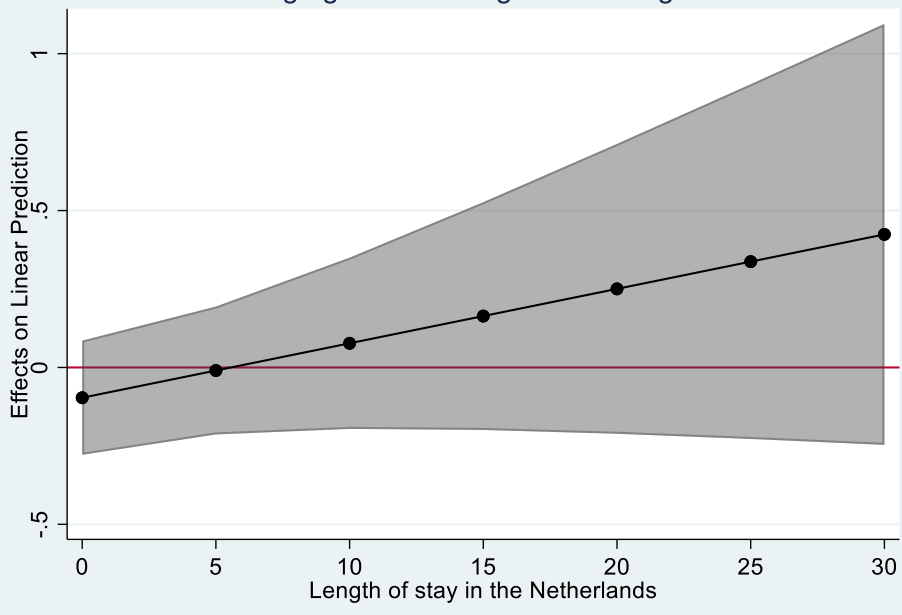

panel d: Turkish migrants in the Netherlands

Figure A.2. Average Marginal Effects (AME) of acculturation effect on the association between sense of belonging to the home country and acceptance of gay marriage per origin- and receiving country 
